\title{
Jenis-Jenis Capung (Odonata: Libellulidae) pada Kawasan Persawahan di Desa Serdang Menang
}

\author{
Ari Sugiarto \\ Email: sugiartoari13@gmail.com
}

\begin{abstract}
Abstrak
Capung (Odonata) dari famili Libellulidae memiliki jumlah spesies paling banyak dibanding famili lainnya. Spesies capung dari famili libellulidae ini cukup banyak ditemukan pada kawasan persawahan. Desa Serdang Menang memiliki kawasan persawahan yang cukup luas. Keberadaan capung pada kawasan persawahan dapat mengindikasikan kualitas ekosistem yang baik. Mengetahui jenis-jenis capung pada kawasan persawahan di Desa Serdang Menang sangat menarik untuk dilakukan dalam upaya memberikan gambaran kualitas ekosistem persawahan tersebut. Hasil dari penelitian didapatkan 11 spesies capung dari 11 genus dengan status konservasi semua spesies yang didapat yaitu Least Concern (LC). Pengaruh musim hujan dan kemarau sangat mempengaruhi populasi capung selain itu spesies capung Brachydiplax chalybea dan Neurothemis tullia hanya dapat ditemukan pada musim hujan. Total 11 spesies capung yang ditemukan dapat memberikan gambaran kualitas ekosistem persawahan yang masih baik.
\end{abstract}

Kata kunci: Capung (Odonata: Libellulidae), Desa Serdang Menang, Kawasan persawahan

\section{Pendahuluan}

Capung (Odonata) merupakan salah satu objek penelitian yang paling banyak diminati yang dapat dilihat dengan meningkatnya jumlah publikasi ilmiah penelitian tentang capung dari tahun ke tahun (Jimenez et al., 2016). Capung merupakan serangga yang pada umumnya memiliki habitat pada kawasan perairan tawar seperti pada sungai, sawah, danau, rawah, dan kolam (Susanti, 1998; Rizal dan Mochamad, 2015). Salah satu habitat capung yang populasinya cukup banyak yaitu pada kawasan persawahan dan capung dari famili Libellulidae memiliki jumlah spesies paling banyak dibanding spesies dari famili lainnya, ini dapat dilihat dari hasil penelitian Ghahari et al. (2009) didapatkan 23 spesies capung pada kawasan persawahan dengan rincian 12 spesies dari famili Libellulidae, 5 spesies dari famili Coenagrionidae, 1 spesies dari famili Euphaeidae, 4 spesies dari famili Aeshnidae, dan 1 spesies dari famili Corduliidae. Penelitian Rohmare et al. (2016) ditemukan 19 spesies capung dari famili Libellulidae pada kawasan persawahan.

Desa Serdang Menang merupakan salah satu desa di Kecamatan Sirah Pulau Padang, Kabupaten Ogan Komering ilir yang memiliki kawasan persawahan yang cukup luas (Sugiarto, 2018). Sawah di Desa Serdang Menang termasuk kedalam jenis sawah tadah hujan. Keberadaan capung pada kawasan persawahan dinilai sangat penting sebagai indikator kualitas ekosistem. Tersedianya data jenis-jenis capung pada kawasan persawahan di Desa Serdang Menang dapat membantu dalam menilai kualitas ekosistem persawahan di Desa Serdang Menang, karena itu perlu dilakukan pendataan jenis-jenis capung (Odonata: Libellulidae) pada kawasan persawahan di Desa Serdang Menang, dengan pertimbangan capung dari famili Libellulidae populasinya lebih banyak dibanding dengan famili lainnya. Penelitian ini bertujuan untuk mengetahui jenis-jenis capung pada kawasan persawahan di Desa Serdang Menang. 


\section{Metode Penelitian}

Penelitian ini dilaksanakan pada bulan Oktober 2018 - September 2019 di kawasan persawahan Desa Serdang Menang. Koleksi capung dilakukan dengan menggunkaan jaring serangga (Hanum et al., 2013) dan juga difoto secara langsung menggunakan camera ponsel. Koleksi capung dilakukan pada pagi dan sora hari (Neog dan Samiron, 2016). Sampel capung yang didapat dari jaring serangga langsung di foto diatas kertas milimeter blok dengan menggunakan camera ponsel dan setelah di foto capung dilepaskan kembali untuk menjaga kelestariannya.

Identifikasi sampel capung dilakukan dengan mencocokkan foto sampel dengan foto spesies yang telah diidentifikasi pada website identifikasi capung.

\section{Hasil dan Pembahasan}

Berdasarkan penelitian yang telah dilakukan, diperolah 11 spesies capung
(Odonata: Libellulidae) dari total 11 genus (Tabel 1). 11 Spesies capung dapat ditemukan semuanya pada musim hujan, sedangkan pada musim kemarau spesies capung Brachydiplax chalybea dan Neurothemis tullia tidak dapat ditemukan. Selain itu, dimusim kemarau spesies capung lainnya juga sulit ditemukan karena populasinya yang sedikit, hal ini dapat dikarenakan pada musim kemarau air yang tergenang pada kawasan persawahan menjadi kering. Penelitian Rohmare et al. (2016) juga menunjukkan bahwa populasi capung lebih banyak dimusim hujan dibanding pada saat musim kemarau. Menurut Susanti (1998) dalam Rizal dan Mochamad (2015), habitat capung umumnya terdapat pada kawasan perairan tawar. Hal ini dapat diartikan bahwa dengan tersedianya air tergenang pada kawasan persawahan sangat penting terhadap keberadaan dan populasi capung.

Tabel 1. Jenis - jenis capung (Odonata: Libellulidae) pada kawasan persawahan di Desa Serdang Menang

\begin{tabular}{ccc}
\hline No & Spesies & Nama umum \\
\hline 1 & Acisoma panorpoides & Trumpet tail \\
2 & Brachydiplax chalybea & Blue dasher \\
3 & Brachythemis contaminata & Ditch jewel \\
4 & Crocothemis servilia & Ruddy marsh skimmer \\
5 & Erythemis peruviana & Flame-tailed pondhawk \\
6 & Neurothemis fulvia & fulvous forest skimmer \\
7 & Neurothemis intermedia & Paddyfield Parasol \\
8 & Neurothemis tullia & Pied- paddy skimmer \\
9 & Orthetrum sabina & Slender skimmer \\
10 & Rhyothemis phyllis & Yellow-striped Flutterer \\
11 & Tholymis tillarga & Coral-tailed cloud wing \\
\hline
\end{tabular}

Satus konservasi semua spesies capung yang ditemukan yaitu Least Concern (LC) berdasarkan IUCN Red List. Spesies capung Brachydiplax chalybea dan Neurothemis tullia sangat jarang ditemukan pada saat melakukan penelitian, hal ini tentunya perlu dilakukan upaya konservasi untuk menjaga kelestarian dari spesies capung tersebut dan spesies capung lainnya.
Jumlah spesies capung yang melimpah pada kawasan persawahan tentunya dapat dikatakan bahwa kualitas kawasan tersebut masih baik. Menurut Neog dan Samirog (2016) capung dapat menjadi indikator yang baik, hal ini dapat dilihat dari kelimpahan dan distribusinya pada suatu kawasan. 


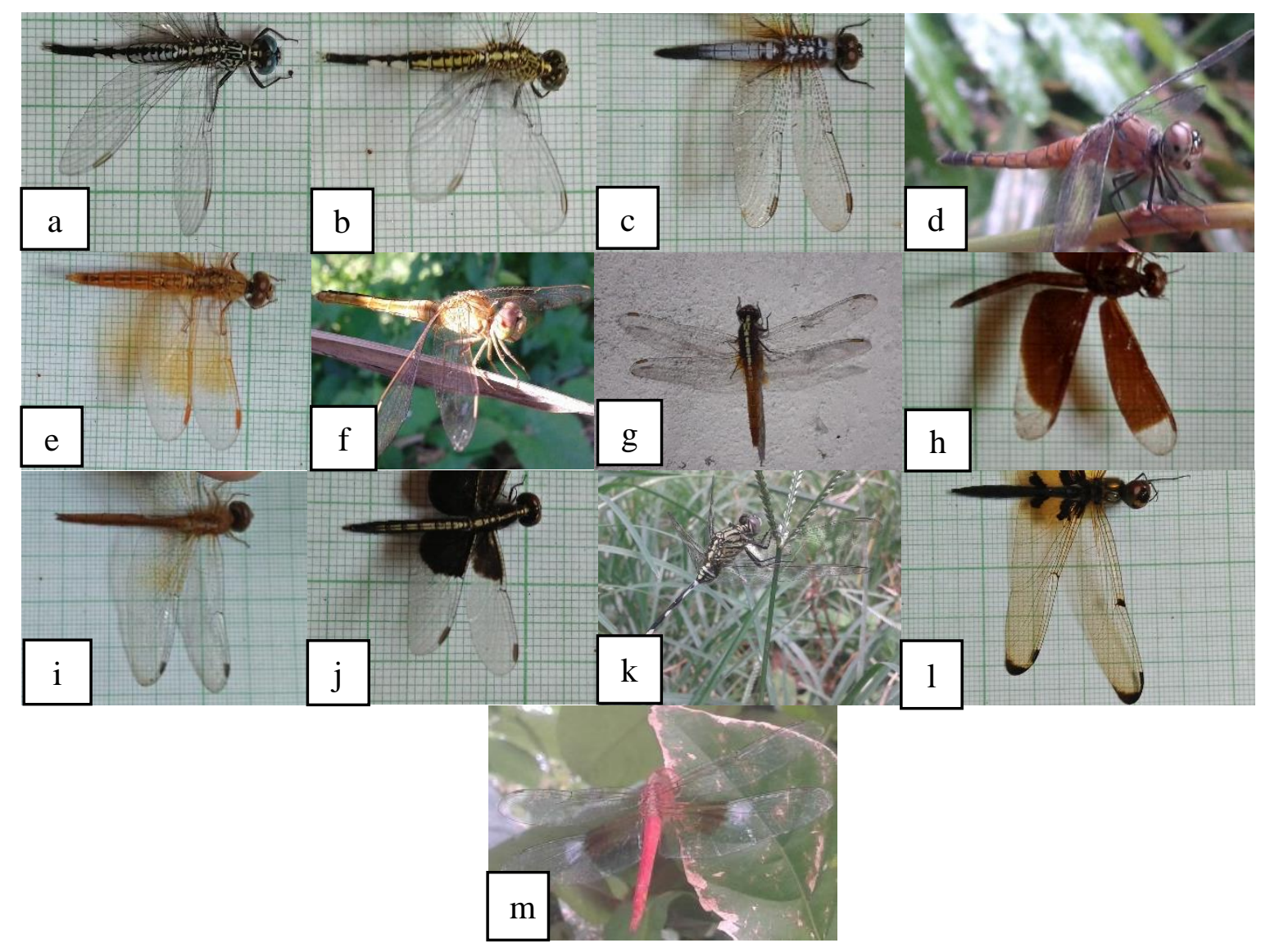

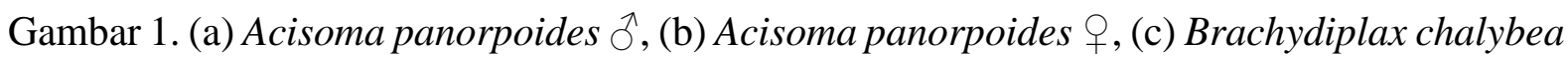
$\widehat{O}$, (d) Brachydiplax chalybea $\bigcirc$, (e) Brachythemis contaminata, (f) Crocothemis servilia, (g) Erythemis peruviana, (h) Neurothemis fulvia, (i) Neurothemis intermedia, (j) Neurothemis tullia, (k) Orthetrum sabina, (1) Rhyothemis phyllis dan (m) Tholymis tillarga

\section{Kesimpulan}

Total 11 spesies dari 11 genus capung famili Libellulidae yang ditemukan pada kawasan persawahan di Desa Serdang Menang, ini dapat memberikan gambaran kualitas lingkungan yang baik. Status konservasi semua spesies yang ditemukan yaitu Least Concern (LC) berdasarkan IUCN Red List, namun perlu diperhatikan bahwa spesies capung Brachydiplax chalybea dan Neurothemis tullia sangat jarang ditemukan. Adanya upaya konservasi dapat menjaga kelestarian spesies capung tersebut dan capung lainnya.

\section{Daftar Pustaka}

Ghahari, H., Mehrdad, T., Hamid, S., Hadi, S dan Sohrab, I. 2009. Odonata
(Insecta) from Northern Iran, with Comments on Their Presence in Rice Fields. Munis Entomology \& Zoology. 4(1): 148-154.

Hanum, S. O., Siti, S dan Dahelmi. 2013. Jenis-jenis Capung (Odonata) di Kawasan Taman Satwa Kandi Kota Sawahlunto, Sumatera Barat. Jurnal Biologi Universitas Andalas. 2(1): 71-76.

Jimenez, G. V., Allison, M. D dan Christopher, H. 2016. Dragonflies and Damselflies (Odonata) in Urban Ecosystems: A review. European Journal of Entomology. 113(27): 217-232. 
Neog, N dan Samiron, M. R. 2016. Dragonfly Diversity in Two Different Ecosystems in and Around Assam University, Silchar (Ecoforest and Irongmara). Journal of Entomology and Zoology Studies. 4(4): 184-190.

Rizal, S dan Mochamad, H. 2015. Inventarisasi Jenis Capung (Odonata) pada Areal Persawahan di Desa Pundenarum Kecamatan Karangawen Kabupaten Demak. BIOMA. 17(1): 16-20.
Rohmare, V. B., Darshana, M. R dan B. M. Parasharya. 2016. Diversity and Population Dynamics of Odonata (Insecta: Odonata) in Rice Growing Area of Central Gujarat. Journal of Biological Control. 30(3): 149157

Sugiarto, A. 2018. Inventarisasi Belalang (Orthoptera: Acrididae) di Perkebunan dan Persawahan Desa Serdang Menang, Kecamatan Sirah Pulau Padang, Kabupaten Ogan Komering Ilir. Kumpulan Artikel Insect Village. 1(3): 7-10. 